\title{
New fundamental and environmental aspects of atmospheric corrosion $^{(\cdot)}$
}

\author{
C. Leygraf*
}

\begin{abstract}
Atmospheric corrosion involves chemical, electrochemical, and physical processes in three phases (solid, liquid, and gas) and two interfaces (solid/liquid and liquid/gas). Because of inherent experimental and conceptual difficulties, scientific efforts to characterize this highly complex interfacial regime came relatively late into the field. With the access and development of surface and interface sensitive analytical techniques, it has lately become possible to perform molecular in situ analyses of the interfaces involved in atmospheric corrosion. This lecture presents some highlights from our fundamental research in atmospheric corrosion, performed at the Royal Institute of Technology in Stockholm, Sweden. It includes results from the most recent efforts in our research group to provide a molecular understanding of the interfacial regime that governs atmospheric corrosion. Using copper or zinc as substrate and carboxylic acid as corrosion stimulator in the humidity-containing atmosphere, results have been obtained with particular emphasis on probing the metal oxide/water interface (by infrared reflection absorption spectroscopy (IRAS) combined with the quartz crystal microbalance (QCM) and sum frequency generation (SFG)) and the water/gas interface (by SFG), respectively. While research in atmospheric corrosion traditionally has aimed at understanding how the environment influences the metal, the opposite question- how the metal influences the environment during atmospheric corrosion- may be of equally technical importance. Some examples of on-going research on new environmental aspects of atmospheric corrosion of zinc will also be presented.
\end{abstract}

Keywords

Atmospheric corrosion; Copper; Zinc; Carboxylic acids; In-situ analysis; Interfaces.

\section{Nuevos aspectos fundamentales y ambientales de la corrosión atmosférica}

Resumen

Palabras clave

\begin{abstract}
La corrosión atmosférica implica procesos químicos, electroquímicos y físicos en tres fases (sólido, liquido y gas) y dos interfases (sólido/líquido y líquido/gas). A causa de dificultades experimentales y conceptuales los esfuerzos científicos para caracterizar el proceso, interfacial, altamente complejo, han llegado con relativo retraso a este campo científico. Con el acceso y desarrollo de técnicas analíticas de superficie e interfase de gran sensibilidad, ha sido posible últimamente llevar a cabo "in situ" análisis moleculares de las interfases involucradas en la corrosión atmosférica. Este artículo presenta algunos aspectos relevantes de la investigación fundamental llevada a cabo en el Royal Institute of Technology de Estocolmo, Suecia. Incluye resultados de los esfuerzos más recientes de nuestro grupo de investigación para elaborar un retrato del régimen interfacial que gobierna la corrosión atmosférica utilizando cobre o cinc como sustrato y un ácido carboxílico como estimulador de la corrosión en una atmósfera húmeda. Se han obtenido resultados que muestran con especial énfasis la interfase óxido metálico/agua, mediante espectroscopia de infrarrojo de absorción-reflexión (IRAS) combinado con microbalanza de cristal de cuarzo (QCM), y la interfase agua/gas mediante generación de suma de frecuencias (SFG). Mientras que la investigación en corrosión atmosférica tradicionalmente ha incidido en el conocimiento del efecto ambiental en el metal, el aspecto opuesto, es decir, de cómo el metal afecta al medioambiente durante el proceso de corrosión atmosférica, puede ser igualmente de gran importancia técnica. En el trabajo se presentan algunos ejemplos de investigaciones actualmente en marcha sobre nuevos aspectos ambientales de la corrosión atmosférica del cinc.
\end{abstract}

Corrosión atmosférica; Cobre; Cinc; Ácidos carboxílicos; Análisis in-situ; Intercaras.

\section{INTRODUCTION}

Atmospheric corrosion was for most of the $20^{\text {th }}$ century a subject of engineering study, largely with empirical approaches. In the last decade or so it became possible to perform more well-controlled laboratory and field studies, both indoors and outdoors, as well as computer model investigations

\footnotetext{
(•) The paper is a summary of a lecture presented during celebration of the 60th Anniversary of Metallurgical Research in CSIC on Nov 26 , 2008 , in Madrid, Spain. Trabajo leído en noviembre de 2008 durante los actos conmemorativos del 60 Aniversario del CENIM.

* Royal Institute of Technology, Division of Corrosion Science, Dr. Kristinas väg 51, SE-10044 Stockholm, Sweden. www.corrosionscience.se.
} 
of the most important atmospheric corrosion processes.

The intent of this lecture is to provide results from ongoing activities aiming at a more molecular understanding of atmospheric corrosion. These activities are based on earlier developments in the research group at the Royal Institute of Technology of in situ analysis of the metal/atmosphere interfacial regime based on four independent techniques, namely infrared reflection absorption spectroscopy (IRAS, monitors the surface chemistry during atmospheric corrosion) ${ }^{[1]}$, quartz crystal microbalance (QCM, integrated with IRAS, monitors changes in mass) ${ }^{[2]}$, atomic force microscopy (AFM, displays surface topography changes) ${ }^{[3]}$ and sum frequency generation (SFG, reveals molecular information from the solid/liquid or the liquid/gas interface) ${ }^{[4]}$. The model systems studied in this work contain either copper or zinc as metal substrates and carboxylic acids-formic acid $(\mathrm{HCOOH})$, acetic acid $\left(\mathrm{CH}_{3} \mathrm{COOH}\right)$ or propionic acid $\left(\mathrm{C}_{2} \mathrm{H}_{5} \mathrm{COOH}\right)$ - as gaseous corrosion stimulator. The interest in carboxylic acids goes back to earlier findings from indoor exposed metals, where the pronounced role of organic indoor pollutants was explored ${ }^{[5]}$.

Results will also be presented to illustrate how atmospheric corrosion may induce environmental effects and how this is studied at the Royal Institute of Technology.

\section{NEW FUNDAMENTAL ASPECTS OF ATMOSPHERIC CORROSION}

In order to explore the relative importance of the phases and interfaces involved in atmospheric corrosion, the transformation of acetaldehyde to acetic acid/acetate has been studied from an atmospheric corrosion perspective, either through analysis of the solid/liquid interface (IRAS, using zinc as substrate exposed to the aqueous adlayer) or the liquid/gas interface (SFG, using a water solution rather than the aqueous adlayer as substrate exposed to the gas) ${ }^{[6]}$. The initial atmospheric corrosion of zinc induced by either acetaldehyde or acetic acid has been investigated as model systems, and compared with respect to the nature of the corrosion products formed. The effect of relative humidity has also been explored.

The overall conclusion is that acetaldehyde at the water/air interface remains in a hydrated form without transforming into acetic acid or acetate. At the zinc/water interface, on the other hand, both aceraldehyde and acetic acid result in zinc acetate formation. In more general terms, this conclusion suggests a superior role of the solid/liquid interface over the liquid/gas interface. In what follows we consider the solid/liquid interface in more detail using copper and carboxylic acids as ingredients of our model system.

A specifically designed quantification procedure for in situ analysis has been developed based on integration of IRAS and QCM. This procedure enables the nature and quantity of different species to be identified during initial atmospheric corrosion of copper exposed to humidified air with addition of a carboxylic acid ${ }^{[7]}$. The results presented are based on copper films on a quartz crystal exposed to the three smallest carboxylic acids. The total mass increase caused by the exposure is the sum of mass changes due to three species identified during initial atmospheric corrosion: water, cuprite $\left(\mathrm{Cu}_{2} \mathrm{O}\right)$, and copper(II)carboxylate. The relationship between the absorbance band of water could be correlated to the mass increase of water, as previously deduced with QCM. Similarly, a relationship was found between the absorbance band of cuprite and the mass increase caused by cuprite formation (QCM), when coppercoated crystals were exposed to clean humidified air at different relative humidities. The carboxylate mass, finally, was obtained by subtracting the water and cuprite mass changes at each exposure time from the total mass as measured by QCM.

The results for copper in formic, acetic and propionic acid environments can be interpreted through identification of two separate pathways of reactions during initial atmospheric corrosion: protonand ligand (carboxylate)-induced dissolution processes, respectively. A schematic picture of the pathways and reactions involved are principally depicted in figure 1, taking copper as example which has been exposed to humidified air with acetic acid as gaseous corrosion stimulator.

After dissociation of acetic acid (step 1 in fig. 3), both protons and acetate ions may interact with the hydroxylated surface formed upon exposure with the aqueous adlayer. Two reaction pathways can be discerned. The first involves proton-induced dissolution of cuprous ions (steps 2-4), subsequent reaction of cuprous ions with hydroxyl ions produced in the cathodic reaction (step 5), followed by the formation and precipitation of cuprite (step 6). The second pathway involves ligand-induced dissolution of the cuprous ions and release of an aqueous copper (II) carboxylate species from the surface (steps 7-9), and subsequent precipitation of copper (II) carboxylate (step 10) into which water and hydroxyl groups may have been incorporated. Depending on acid, one route seems to dominate over the other. These differences can partly be explained by their 


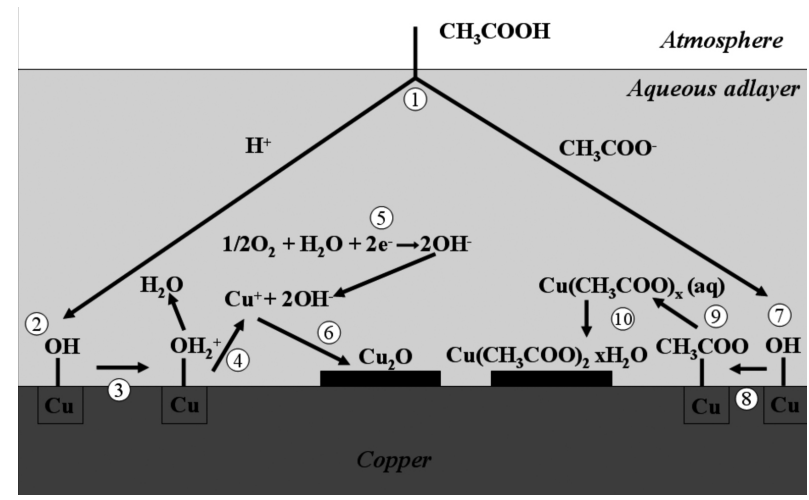

Figure 1. Schematic description of reaction pathways for the formation of copper (I) oxide (step 1 to 6) and copper (II) carboxylate (step 7 to 10) during initial atmospheric corrosion of copper by acetic acid in humidified air.

Figure 1. Descripción esquemática de las etapas de reacción para la formación de óxido de cobre (I) (etapas 1 a 6) y carboxilato de cobre (II) (etapas 7 a 10), durante la corrosión inicial del cobre por ácido acético en aire humidificado.

acid strength and content of non-polar groups. In all, higher acid strength and also higher deposition velocity seem to favour the overall corrosion rate, and also the second pathway governed mainly by carboxylate-induced dissolution of copper.

We next discuss the possible in situ identification of the metal-carboxylate interfacial species by SFG (corresponding to step 8 in figure), and the multi-layer growth of metal-carboxylate films (step 10) as observed by IRAS. Figure 2 displays the spectra from SFG and IRAS for zinc exposed under the same conditions in both cases: $120 \mathrm{ppb}$ of formic acid and $85 \% \mathrm{RH}$. The spectral region of interest highlights the vibrations of the carboxylate group $\left(\mathrm{COO}^{-}\right)$. The vibrational modes of this group in the formate ion adsorbed on zinc oxide is the symmetric stretch at $1350 \mathrm{~cm}^{-1}$ and the antisymmetric stretch at $1630 \mathrm{~cm}^{-1}[8]$.

From the intensity ratio between the symmetric and antisymmetric stretches in the IRAS spectrum, and with the antisymmetric stretch being more intense, it can be concluded that the preferred orientation of zinc formate in the multi-layer films formed also is tilted more towards the surface, but not as pronounced as for the interfacial zinc formate seen in the SFG spectrum. To conclude, formate species could be identified under in situ conditions either as constituent of the multi-layer film or as interfacial species, whereby different orientations of zinc formate were discerned by IRAS and SFG respectively.

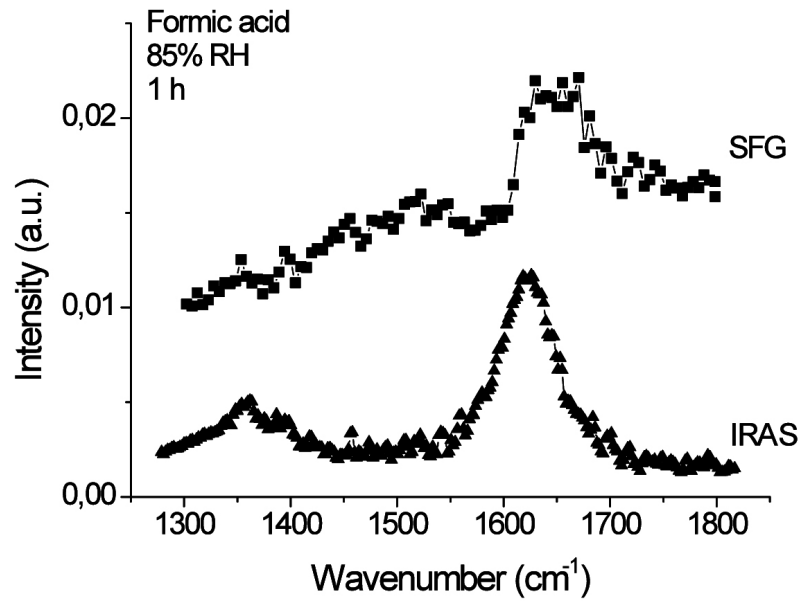

Figure 2. Zinc exposed to formic acid and $85 \%$ $\mathrm{RH}$ for $1 \mathrm{~h}$. Upper: SFG spectrum. Lower: corresponding IRAS spectrum.

Figure 2. Cinc expuesto a ácido fórmico y $85 \%$ de HR durante $1 \mathrm{~h}$. Superior: espectro SFG. Inferior: espectro IRAS correspondiente.

In all, the initial atmospheric corrosion of copper or zinc has been explored in situ with carboxylate acids and humidity as corrosion stimulators. The combination of SFG and IRAS provides unique evidence of the relative importance of the solid/liquid interface over the liquid/gas interface. A deeper insight into the solid/liquid interface has been obtained when integrating IRAS and QCM, whereby the nature and quantity of species could be identified that participate in the carboxylic acid-induced initial atmospheric corrosion of copper. SFG combined with IRAS has furthermore revealed the different nature of zinc-formate species formed during initial stages of zinc induced by formic acid.

\section{NEW ENVIRONMENTAL ASPECTS OF ATMOSPHERIC CORROSION}

In what follows the release and environmental fate of zinc from zinc-containing building materials will be described in some detail. The aim of this environmental study was to provide quantitative data for risk assessment on corrosion-induced zinc runoff rates from commercially available zinc-based construction materials and also to explore its environmental interaction with various soils representative of Europe. The work consisted of an exposure assessment in Stockholm, Sweden, which involved long-term ( 5 years) annual runoff rates from 14 zinc-based roofing materials with 
generated data on total zinc concentrations and chemical speciation. The study consisted also of an effect assessment with generated data on bioavailability and ecotoxicity of real field samples, both at the immediate release situation and after interaction with the investigated soils. The study was triggered by the circumstance that few investigations have been performed to elucidate the fate of metal release from source to recipient by considering changes in chemical speciation, bioavailability and ecotoxicity of the released metal heading towards a recipient.

A unique set of data on annual runoff rates of zinc from different zinc-based building materials has been generated, based on exposure conditions in Stockholm. They range from 0.07 to $2.5 \mathrm{~g} \mathrm{~m}^{2} \mathrm{yr}^{-1}$, depending on the presence of a barrier, such as a paint system, a layer of chromate, or a thin organic coating-layer. For other urban sites where no runoff rates of zinc are available, or not possible to measure, empirical relations can be used to predict the runoff rate of uncoated zinc. Such predictions require information on annual average $\mathrm{SO}_{2}$ concentrations, annual precipitation quantities and area and inclination of the exposed zinc surface.

However, information on zinc runoff rates or total zinc concentration in runoff water is not sufficient for adequate effect assessments. Additional necessary information includes knowledge on the chemical speciation of released zinc. Chemical speciation modelling of runoff water at the immediate release situation shows the majority of the total zinc concentration to be in its free ionic form, the hydrated zinc ion $\left(\mathrm{Zn}\left(\mathrm{H}_{2} \mathrm{O}\right)_{6}{ }^{2+}\right)$. This turns out to be the most bioavailable form of zinc. Upon interaction with nearby absorbing surfaces, such as those in soil, the total zinc concentration and its chemical speciation change drastically. Upon passage of zinc-containing water through soil, the total zinc concentration in the experiments performed was reduced with 98 to $99 \%$ during 15 years of simulated exposure, and the concentration of $\mathrm{Zn}\left(\mathrm{H}_{2} \mathrm{O}\right)_{6}{ }^{2+}$ in the remaining zinc-containing runoff solution was further reduced by $60-70 \%$. After 72 hours, the growth of the green algae $R$. Subcapitata was reduced with $50 \%$ at zinc concentrations of $69 \mu \mathrm{g} \mathrm{1^{-1 }}$, corresponding to the concentration found at the immediate release situation, but rarely after soil interaction.

In all, this multidisciplinary effort illustrates that zinc, similar to other investigated metals copper, chromium and nickel, mainly is present in its most bioavailable form immediately after release. For zinc the most bioavailable form is the free hydrated zinc ion, $\mathrm{Zn}\left(\mathrm{H}_{2} \mathrm{O}\right)_{6}{ }^{2+}$. However, during environmental entry, the bioavailable part that interacts with organisms such as the green algae R. Subcapitata, is substantially reduced, and forms other, much less bioavailable zinc-containing species. Moreover, zinc is largely retained already in the immediate vicinity of the release location.

Figure 3 summarizes important observations and conclusions regarding the runoff and environmental fate of zinc under current exposure conditions. Further details are given ${ }^{[9]}$.

\section{CONCLUDING REMARKS}

Through development and application of new experimental techniques to probe the interfacial regime between the metal and its surrounding atmosphere, and by placing atmospheric corrosion into a broader environmental perspective, we gradually gain deeper insight into this most important form of corrosion. Recent activities from our research group at the Royal Institute of Technology in Stockholm have herein been categorized into a fundamental part and an environmental part. The fundamental part is based on our efforts to characterize the interfacial regime between zinc or copper and the atmosphere. It highlights the importance of the zinc/liquid interface over the liquid/atmosphere and provides quantitative

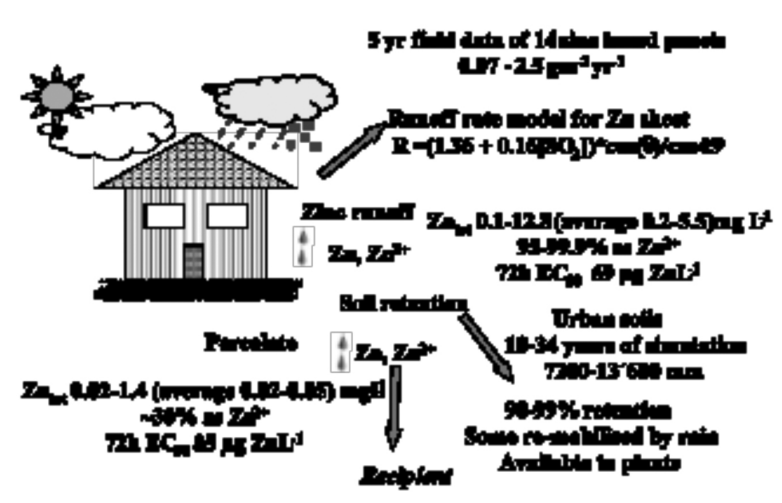

Figure 3. Key conclusions obtained regarding the environmental fate of corrosion-induced zinc runoff from zinc-based building materials. A more detailed description and presentation of results is given in $^{9}$.

Figure 3. Conclusiones relevantes obtenidas con relación al destino ambiental de los productos de corrosión del cinc en materiales de construcción de base cinc. Una descripción más detallada y presentación de resultados se encuentra en Ref. 9. 
in situ identification of different surface species of crucial importance for the initial atmospheric corrosion.

The environmental part describes the corrosioninduced zinc release from zinc-based materials used in outdoor constructions. It clearly shows that zinc upon corrosion-induced release is present in its most available form. During environmental entry, the bioavialable part is substantially reduced and forms other, much less, bioavailable zinc-containing species. Zinc is also commonly retained in the immediate vicinity of the release location.

\section{Acknowledgements}

The author greatfully acknowledges most valuable contributions from co-authors at the Royal Institute of Technology: Prof. Inger Odnevall Wallinder, Dr. Magnus Johnson, Dr. Harveth Gil, Dr. Dan Persson, Dr. Ted Aastrup and Dr. Sofia Bertling.

\section{REFERENCES}

[1] D. Persson and C. Leygraf, J. Electrochem. Soc. 142 (1995) 1459.

[2] T. Aastrup and C. Leygraf, J. Electrochem. Soc. 144 (1997) 2986.

[3] M. Wadsak, M. Schreiner, T. Aastrup and C. Leygraf, Surf. Sci. 454 (2000) 246.

[4] C.M. Johnson, E. Tyrode, S. Baldelli, M.W. Rutland and C. Leygraf, J. Phys. Chem. 109 (2005) 321.

[5] D. Persson and C. Leygraf, J. Electrochem. Soc. $142(1995) 1468$.

[6] C. M. Johnson, E. Tyrode and C. Leygraf, J. Electrochem. Soc. 153 (2006) B113.

[7] H. Gil, and C. Leygraf, J. Electrochem. Soc. 154 (2007) C272.

[8] W.T. Petrie and J.M. Vohs, Surf. Sci. 245 (1991) 315.

[9] S. Bertling, I. Odnewall, C. Leygraf and D. Berggren, Science of the total environment 367 (2005) 908. 